\title{
The Pathogenesis of Tumour Hypoglycaemia: Blocks of Hepatic Glucose Release and of Adipose Tissue Lipolysis*
}

\author{
A. Jakob, U.A. Meyer, R. Flury, W.H. Ziegler, A. Labhart and E.R. Froesch \\ Metabolic Unit, Department of Medicine, University of Zurich and Department of Medicine, Kantonsspital St. Gallen,
} Switzerland

Recoived March 6, 1967

Summary. Earlier findings on the pathogenesis of tumour hypoglycaemia [15] were confirmed and extended in a second patient with this disease. - A block of hepatic glucose release was found to be the main cause of hypoglycaemia in both patients suffering from large tumours of non-endocrine origin. The free fatty acid level failed to increase upon hypoglycaemia. Low free fatty acid levels correlated with an increased rate of glucose assimilation and glucose oxidation. - Immunoreactive, suppressible and nonsuppressible ILA measured in vitro and in vivo were normal. - However, the serum of patient Z.B. inhibited lipolysis of adipose tissue in vitro to a greater extent than serum of normal subjects. This difference was no longer present after dialysis of the sera and the antilipolytic activity was now found in the diffusate. - The block of hepatic glucose release may be overcome by a pharmacological dose of intravenous glucagon. The block of hepatic glucose release is of paramount importance for the development of hypoglycaemia since the pharmacological blocking of lipolysis alone does not lead to hypoglycaemia, although it may increase glucose assimilation and glucose oxidation. - An attempt is being made to characterize further the antilipolytic substance which is present in increased amounts in the serum of patients with tumour hypoglycaemia.

La pathogénèse de l'hypoglycémie par tumeurs: Inhibition de la libération du glucose dans le foie et de la lipolyse dans le tissu adipeux

Résumé. Le métabolisme glucidique et lipidique a été étudié chez un patient avec un fibrosarcome rétropéritonéal récidivant a.ceompagné de graves attaques d'hypoglycémie. Les notions obtenues en 1963 chez un malade montrant la même symptomatologie [15] ont été confirmées et approfondies. - Dans les deux cas la production de glucose par le foie était presque complètement bloquée. En outre ces sujets étaient incapables d'augmenter le taux des acides gras libres plasmatiques pendant la chute prononcée de la glycémie. - Il existait une corrélation étroite entre le taux constamment bas des acides gras libres du plasma et une assimilation et oxydation accélérée du glucose sanguin. - La libération de glucose par le foie pouvait être stimulée par une dose pharmacologique de glucagon. - Les taux d'insuline immunologique du sérum ainsi que l'activité insulinique supprimable et non-supprimable étaient toujours normaux. - Aucune substance "insulinoïde" n'a pu être démontrée par des tests in vivo et in vitro. - D'autre part, le sérum de la malade produisait une inhibition plus

* This work was supported by grants from the Schweizerische Nationalfonds (3336) and from the U.S. Public Health Service (AM 5387). accentuée de la lipolyse in vitro que le sérum d'un sujet normal. - Après dialyse, le sérum avait perdu son activité antilipolytique qui était retrouvée en partie dans le dialysat. - Le facteur principal de la pathogenèse de l'hypoglycémie tumorale semble être l'inhibition de la production de glucose par le foie, puisqu'un blocage pharmacologique de la lipolyse ne suffit pas pour déclencher une hypoglycémie. - L'inhibition de la lipolyse accélère d'autre part l'assimilation et l'oxydation du glucose sanguin et aggrave par cela considérablement l'hypoglycémie.

Pathogenese der Tumorhypoglykämie: Blockierung der Glucosefreisetzung aus der Leber und der Lipolyse im Fettgewebe

Zusammenfassung. Bei einer Patientin mit rezidivierendem, retroperitonealem Fibrosarkom und Tumorhypoglykämie wurde der Kohlenhydrat- und Fettstoffwechsel untersucht. Es konnten dabei die Resultate einer früheren Untersuchung an einer Patientin mit derselben Symptomatologie [15] bestätigt und erweitert werden. - In beiden Fällen war die Glucoseausschüttung aus der Leber weitgehend blockiert und die Patienten waren unfähig, auf einen Blutzuckerabfall mit einer vermehrten Abgabe von Fettsäuren aus dem Fettgewebe ins Plasma zu reagieren. Eine Korrelation zwischen niedrigen Plasmawerten von freien Fettsäuren und einer beschleunigten Glucose-Assimilation und -Oxydation war nachweisbar. - Auf die intravenöse Gabe einer pharmakologischen Dosis von Glucagon reagierte die Leber durch prompte Ausschüttung von Glucose. - Die Werte des immunoreaktiven Insulins, sowie der hemmbaren und nicht hemmbaren ILA im Serum waren immer normal. Hingegen wurde durch Serum der Patientin die Lipolyse des Fettgewebes in vitro stärker gehemmt als durch Kontrollseren. Nach Dialyse war zwischen Patienten- und Normalserum kein Unterschied in der antilipolytischen Aktivität mehr feststellbar. Ein Teil der antilipolytischen Aktivität konnte im Dialysat des Patientenserums wieder gefunden werden. - Die Hemmung der Glucoseabgabe aus der Leber scheint für die Pathogenese der Hypoglykämie ausschlaggebend zu sein, da die pharmakologische Hemmung der Lipolyse allein keine Hypoglykämie verursacht. - Die Lipolysehemmung kann jedoch die Glucose-Assimilation und -Oxydation beschleunigen und damit den Blutzuckerabfall verstärken.

Key-words: Hypoglycaemia, extrapancreatic tumour hypoglycaemia, paraneoplastic syndrome, glucose turnover, glucose assimilation, free fatty acids, lipolysis, antilipoly. sis, hepatic glucose release, plasma insulin, insulin-like activity, urinary catecholamines, plasma growth hormone. 
Mesenchymal and epithelial tumours of non-endocrine origin occasionally produce hypoglycaemia. Although more than 200 such cases have been reported, the pathogenesis of hypoglycaemia associated with malignant tumours which do not originate from the pancreas is still unknown (reviewed in [22], [19] and [26a].).

Several theories have been proposed to explain tumour hypoglycaemia and have recently been reviewed by UNGER [33]. Increased amounts of circulating insulin and / or insulin-like substances, excessive utilization of glucose by the tumour or a combination of the two were most often incriminated as the cause of this type of hypoglycaemia.

In 1963 , a patient with hypoglycaemia associated with a metastasizing nephrosarcoma was studied in our elinic [15]. The findings suggested that hypoglycaemia in this patient was due to several metabolic disturbances rather than to one single cause. The blocking of hepatic glucose release and of adipose tissue lipolysis in association with an elevated glucose consumption by the tumour was proved to be responsible for the development of hypoglycaemia in this patient. Antibody suppressible and nonsuppressible ILA were present in normal amounts in the blood of this patient and no insulin-like material could be extracted from the tumour. A careful review of the literature yielded poor evidence for increased insulin-like material in the blood of these patients, and an increased glucose uptake by peripheral tissues has never been proved $[19,15,25]$.

We have had the opportunity to confirm and to extend these data in a second patient with a retroperitoneal sarcoma and with severe hypoglycaemia. Serum of this patient inhibited lipolysis of adipose tissue in vitro to a greater extent than did normal serum. The substance responsible for the inhibition of lipolysis was dialyzable and consequently of small molecular weight. It has not yet been identified and it is not certain whether it, or a related substance may be responsible for the blocking of hepatic glucose release. The results of this study have been presented elsewhere in preliminary form [20].

\section{Case report}

In this 52 year-old female patient, Z.B., Journal Number $315 / 66$, a retroperitoneal fibrosarcoma was totally resected in January 1963. No metastases were found at that time. Till 1965 the patient was without complaints. In September 1965 the patient experienced attacks of hypoglycaemia, which were at first slight, but soon became severe. There was no evidence of metastases or of local recurrence of the tumour at this time. In January 1966 the patient was admitted to the Metabolic Unit of the Department of Medicine in Zurich for further investigation of the hypoglycaemic attacks, which had become extremely severe. The patient avoided nocturnal hypoglycaemia by taking $20 \mathrm{~g}$ of sucrose every two hours. The liver was grossly enlarged, firm, its edge uneven and it rapidly increased in size. During the stay at the hospital the need for glucose varied considerably. During episodes of two to three days up to $600 \mathrm{~g}$ of glucose had to be administered over 24 hours to maintain the blood sugar between 40 and $70 \mathrm{mg} \%$. Diazoxide was given thera. peutically over a period of two to three months in a dosage of 150 to $225 \mathrm{mg}$ per day. Whether or not it had any effect on glucose metabolism cannot be stated with certainty since the spontaneous fluctuations of glucose assimilation were considerable. Diazoxide did not prevent hypoglycaemia, but appeared to delay its development. The patient was treated with Endoxan, 100-150 mg per day over a period of several months without any clear-cut effects on tumour growth or hypoglycaemia. At home, the daily intake of glucose varied from 200 to $600 \mathrm{~g}$. The cessation of diazoxide therapy enforced by gastrointestinal side effects did not appreciably alter the need for glucose. The patient's blood sugar $45 \mathrm{~min}$. after breakfast was $46.1 \pm 3.5 \mathrm{mg} \%$ (mean \pm SEM, $n=16$ ). The slightest work in the house immediately led to hypoglycaemic attacks.

In July 1966, the patient had, for the first time, signs of obstructive jaundice that rapidly became more severe. She died in August 1966 at home after a coma of several hours duration. The nature of the lethal coma could not be established.

\section{Necropsy findings}

Tumour cachexia was not striking (length: $151 \mathrm{~cm}$, weight: $51 \mathrm{~kg}$ ). In the retroperitoneal region a local recurrence of the tumor was found. The tumor had invaded and compressed the surrounding loops of the ileum and the left ureter and had led to a hydronephrosis of the left kidney. Histologically the tumour was described as a well differentiated fibrosarcoma. The liver was deformed by large metastases and showed a cholostasis with icterus. Smaller metastases were found along the paraaortic lymphatic ducts, on the diaphragm, on the mesosigmoid and in both kidneys. In the thyroid gland and the right adrenal gland minute metastatic nodules were found. The pancreas and the islets looked normal. A differential stain for A- and B-islet cells was not performed.

\section{Methods}

Blood glucose was measured with glucose oxidase [1]. Glycerol and lactate were enzymatically determined [35].

Plasma free fatty acids were extracted and titrated according to GoRDoN [17]. Epinephrine and norepinephrine were estimated fluorimetrically [2]. ${ }^{14} \mathrm{C}$-labelled glucose was isolated from the blood in the form of osazone $^{1}$. The total lipids of the rat fat pads were extracted by the method of Folch, LEES and STANLEY [11]. Glycogen was precipitated with cold ethanol after hydrolysis of the tissue in boiling $30 \% \mathrm{KOH}$. Carrier glycogen was used as a precipitating aid. The glycogen was twice redissolved and reprecipitated and then deposited on a filter paper by suction through a

1 The specifle activity of the serum glucose was obtained by dividing the counts in the osazones by the serum glucose. 
sintered glass filter for counting. All radioactive samples were counted in a low background flow counter and a correction for self-absorption was applied. Details of the isolation and counting procedures used in our laboratory may be found elsewhere [16]. ILA was measured in vitro by the fat pad technique using antiinsulin serum from guinea-pigs for differentiation between suppressible and nonsuppressible ILA $[4,14]$. Insulin-like or insulin-potentiating substances in the blood of this patient were also searched for by injeeting serum together with glucose-6- ${ }^{14} \mathrm{C}$ intravenously into rats and by measuring the incorporation of carbon ${ }^{14}$ into glycogen of the diaphragm and into total lipids of the epididymal fat pads [16]. Immunoreactive insulin and growth hormone were determined by double antibody immunoassays $[18,38]^{1}$. The antilipolytic activity of serum was estimated in vitro by the inhibition of basal glycerol release of adipose tissue from fasted-refed rats [12]. Visking tubing (8/100 FT), rinsed overnight in tap water, was used for dialysis of serum. The glucose assimilation coefficient $\left(K_{G}\right)$ was determined by the intravenous glucose tolerance test according to CoNARD [9].

\section{Results}

\section{Glucose assimilation}

Glucose assimilation was repeatedly estimated in patient Z.B. by intravenous glucose tolerance tests. levels one hour after stopping the administration of glucose were significantly higher on diazoxide therapy than without it.

In an attempt to determine the locus of increased glucose uptake the differences of the glucose concentration between the brachial artery and the femoral vein on the one hand, and the vena cava on the other were measured. It was assumed at the time of the experiment that the vena cava was draining not only the legs but also part of the tumour metastases in the pelvis, an assumption which was proved to be correct at autopsy. The difference in the glucose concentration between artery and vena cava represents the sum fo the glucose uptake by peripheral tissues plus tumour tissue. The tip of the catheter in the vena cava was placed just below the diaphragm. Hence, hepatic handling of glucose did not influence our measurements. The blood sugar was maintained constant at two different levels by constant infusions of glucose. The results of this study are presented in Table 2. At the lower level of blood sugar of $128 \mathrm{mg} \%$ the glucose difference between artery and vena cava was significantly greater than the peripheral arteriovenous difference, indicating that the glucose consumption by the tumour was relatively greater than that of the tissues of the legs. Lactic acid levels were within the normal range, independently of the sampling site (brachial artery: $0.57 \pm 0.04 \mathrm{mg} \%$; vena cava : $0.54 \pm$ $0.01 \mathrm{mg} \%$; femoral vein: $0.58 \pm 0.03 \mathrm{mg} \%$ ).

Table 1. Glucose assimilation coefficient and blood sugar values in patient Z.B. one hour after stopping the infusion of glucose

Influence of the diazoxide and benzohydroflumethazide therapy

\begin{tabular}{|c|c|c|c|c|c|c|}
\hline \multirow[t]{2}{*}{ therapy } & \multicolumn{2}{|l|}{$\boldsymbol{K}_{\mathbf{G}} \cdot 10^{2}$} & \multirow[t]{2}{*}{$P$} & \multicolumn{2}{|c|}{$\begin{array}{l}\text { blood sugar } 1 \text { hour after } \\
\text { stopping constant glucose } \\
\text { infusion, mg/100 ml }\end{array}$} & \multirow[t]{2}{*}{$P$} \\
\hline & & mean $\pm \mathrm{SEM}$ & & & mean \pm SEM & \\
\hline none & $\begin{array}{l}1.82 \\
3.15 \\
1.77 \\
1.47 \\
1.26\end{array}$ & $1.89 \pm 0.10$ & -01 & $\begin{array}{c}-\overline{8} \\
-\overline{21} \\
13\end{array}$ & $14.0 \pm 3.8$ & -0.005 \\
\hline $\begin{array}{l}\text { diazoxide } \\
150-225 \mathrm{mg} / \mathrm{day} ; \\
\text { benzhydroflumethazide } \\
5 \mathrm{mg} / \text { day }\end{array}$ & $\begin{array}{l}0.92 \\
1.21 \\
1.30\end{array}$ & $1.14 \pm 0.01$ & & $\begin{array}{l}70 \\
44 \\
54\end{array}$ & $56.0 \pm 7.6$ & \\
\hline
\end{tabular}

Infusions of glucose were stopped one hour prior to the beginning of the tests. The glycaemia at this time and glucose assimilation coefficients are shown in Table 1. The $K_{G}$ varied from normal to markedly increased values. When the patient was treated with diazoxide $\left(150-225 \mathrm{mg}\right.$ per day) the mean $K_{G}$ was somewhat lower than without therapy but the difference was statistically not significant. Blood glucose

1 We are grateful to Dr. G. ZAHND, Geneva, for his most valuable help in the determination of peptide hormones.

\section{Hepatic glucose release, free fatty acid metabolism} and rate of glucose oxidation

On two occasions $100 \mu \mathrm{C}$ of glucose- $\mathrm{U}_{-}{ }^{14} \mathrm{C}$ were given intravenously together with $16 \mathrm{~g}$ of unlabelled glucose. The blood sugar, the total and the specific activity of serum glucose, the specific activity of the expired $\mathrm{CO}_{2}$ and the free fatty acids were followed over a period of $2 \frac{1}{2} \mathrm{~h}$. On one occasion the patient received no drugs, whereas she was on diazoxide therapy during the other test. As may be seen on the left of figure 1 the glucose assimilation was very rapid. The 
$K_{G}$ was $3.15 \times 10^{-2}$ corresponding to a half-life of blood glucose of only $22 \mathrm{~min}$. Intravenous administration of glucagon ( $1 \mathrm{mg}$ ) led to a sudden rise in blood sugar and it relieved hypoglycaemic symptoms. On another occasion $2 \mathrm{mg}$ of glucagon administered intravenously lead to an increase of the blood sugar from 46 to $129 \mathrm{mg} \%$ within $20 \mathrm{~min} .15 \mathrm{mg}$ of zinc glucagon injected i.m. enabled the patient to and the blood sugar tended to level off at $30 \mathrm{mg} \%$. The block of hepatic glucose release was almost complete. The free fatty acid level was $1.2 \mu \mathrm{eq} / \mathrm{ml}$ at the beginning of the test. It fell to $0.4 \mu \mathrm{eq} / \mathrm{ml}$ during the test. On this occasion hypoglycaemia provoked a clear cut rise to a level of $0.7 \mu \mathrm{eq} / \mathrm{ml} .20 \%$ of the expired $\mathrm{CO}_{2}$ was derived from glucose, i. e. much less than in the first experiment.
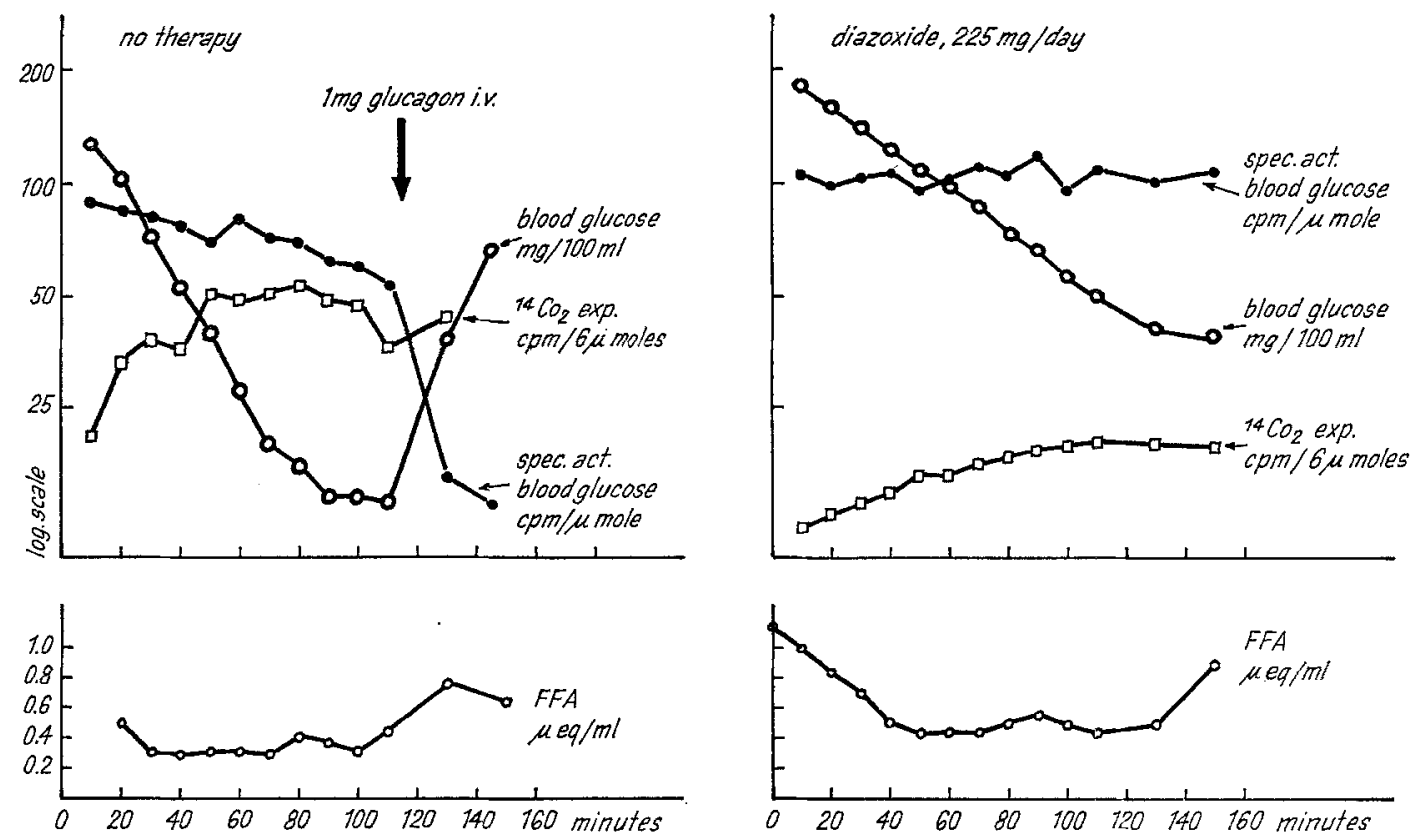

Fig. 1. Metabolism of glucose-U. ${ }^{14} \mathrm{C}$ during the development of spontaneous hypoglycaemia in patient Z.B. on two occasions. $100 \mu \mathrm{C}$ of glucose-U. ${ }^{14} \mathrm{C}$ was administered together with $16 \mathrm{~g}$ of glucose at time 0, i.e. one hour after withholding exogenous glucose. Blood samples were collected from a superficial brachial vein. Expiratory air was sampled through a Ruben non-rebreathing valve in plastic bags, and the $\mathrm{CO}_{2}$ was precipitated as barium carbonate. The specific activity of the expired $\mathrm{CO}_{2}$ is given per $6 \mu$ moles to make the figures comparable with those of the specific activity of the blood glucose

fast during $9 \mathrm{~h}$. before witnessing hypoglycaemic symptoms. These consisted of sweating, dizziness and a disturbing apathy, and they became severe when the blood sugar fell below $20 \mathrm{mg} \%$. Despite severe hypoglycaemia the amount of glucose released from the liver was small as indicated by the curve of the specific activity of serum glucose. The calculated hepatic release was approximately $30 \mathrm{mg}$ of glucose per minute during the sharp fall of the blood sugar, and it did not increase when the blood sugar levelled off at $10 \mathrm{mg} \%$. The labelled glucose administered at the beginning of the test was rapidly oxidized as shown by the sharp increase in the specific activity of the expired $\mathrm{CO}_{2}$. Approximately $60 \%$ of the total expired $\mathrm{CO}_{2}$ was derived from glucose. The concentration of free fatty acids remained low during the whole experiment and did not rise in spite of the very severe hypoglycaemia. During the second test, carried out in the same manner but this time on diazoxide therapy (right of Fig. 1), glucose assimilation was less rapid

\section{Endocrine counterregulation against hypoglycaemia}

Since hormonal counterregulation normally prevents a sustained fall of the blood sugar, the levels of epinephrine, norepinephrine and growth hormone were measured during a fall of blood glucose from $120 \mathrm{mg} \%$ to $10 \mathrm{mg} \%$. When hypoglycaemia developed, a rise was observed in the level of both epinephrine and growth hormone (Fig. 2).

4. Immunoreactive and biological insulin-like activities of the serum

Immunoreactive and suppressible ILA were measured at different levels of blood sugar, varying from 26 to $115 \mathrm{mg} \%$ and they were found to be well within the normal range (Table 3 ). There was no correlation between immunoreactive and suppressible ILA with the blood sugar, indicating that regulation of insulin secretion by the blood sugar was disturbed by the very frequent hypoglycaemic attacks. Nonsuppressible ILA was in the normal range. Serum was injected 
intravenously into rats together with glucose-6- ${ }^{14} \mathrm{C}$ and incorporation of radioactive carbon into glycogen of the diaphragm and into total lipids of the epididymal fat pads was determined (Fig. 3). Whereas serum of the patient and of a normal subject had no effect, $2 \mathrm{mU}$ of crystalline insulin significantly stimulated glucose incorporation.
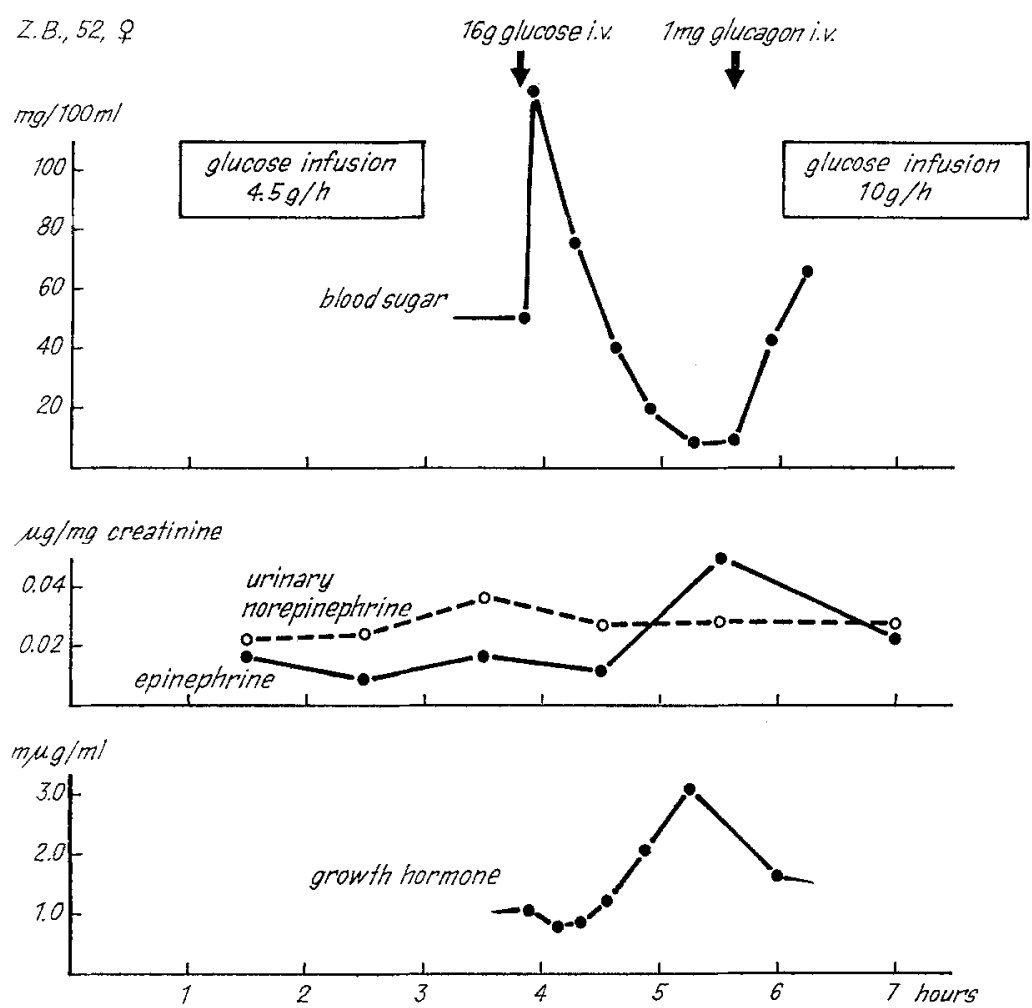

Fig. 2. Endocrine counterregulation in a patient with tumour hypoglycaemia. These measurements were carried out during the same experiment of which other motabolic indices are represented on the left hand side of Fig. 1

Table 2. Superficial and central arterio-venous glucose difference in patient $Z$. B. at two constant blood sugar levels

The central arterio-venous glucose difference represents the sum of the glucose uptake by the metastases of the tumour and by peripheral tissues

\begin{tabular}{lllll}
\hline $\begin{array}{l}\text { blood sugar } \\
\text { (brachial artery) }\end{array}$ & $n$ & \multicolumn{2}{l}{$\begin{array}{l}\text { glucose difference } \mathrm{mg} / 100 \mathrm{ml} \\
\text { mean } \pm \mathrm{SEM}\end{array}$} & $P$ \\
\cline { 2 - 4 } $\begin{array}{l}\text { mg/100 ml } \\
\text { mean } \pm \mathrm{SEM}\end{array}$ & & $\begin{array}{l}\text { brachial artery- } \\
\text { femoral vein }\end{array}$ & $\begin{array}{l}\text { brachial artery- } \\
\text { vena cava }\end{array}$ & \\
\hline $156.6 \pm 1.9$ & 3 & $7.7 \pm 3.8$ & $9.3 \pm 0.1$ & $<0.4$ \\
$128.0 \pm 2.6$ & 4 & $2.5 \pm 0.2$ & $5.2 \pm 1.7$ & $<0.01$
\end{tabular}

5. Antilipolytic effect of the patient's serum on rat adipose tissue in vitro

Crystalline insulin, suppressible and nonsuppressible ILA inhibit the glycerol release of adipose tissue [16]. The experiments represented in Table 4 were carried out in order to investigate whether or not the serum of patient Z.B. contained antilipolytic activities out of proportion to its content of insulin-like activities. The antilipolytic effect of the serum of patient Z.B., in dilutions of $1: 20$ and 1:50, was sigficantly greater than that exerted by serum of a norativity of both sera. The antilipolytic activity of the serum of patient Z.B. still seemed to her than that of the serum of the normal subject, but the difference was not significant. The antilipolytic activity lost from the serum during dialysis was partially recovered in the diffusate.

\section{Discussion}

A block of hepatic glucose release and low serum levels of free fatty acids were found to be common metabolic characteristics in two patients with hypoglycaemia due to nonendocrine tumours. A decreased outflow of glucose from the liver in patients with this disease has also been noted by BuTtERFIELD and by Samols [6, 28]. A low serum level of free fatty acids may theoretically result from increased utilization rather than from a low rate of pro. duction. However, since their utilization generally parallels their concentration and decreases as their level falls, a low concentration of free fatty acids may be interpreted as indicating a decreased release of free fatty acids by adipose tissue. We will henceforth speak of a block of lipolysis although this may not be the only explanation for the low free fatty acids.

The combination of these two metabolic blocks is essential for the rapidity with which this type of hypoglycaemia supervenes. The metabolism of glucose-U- ${ }^{14} \mathrm{C}$ seems to be linked to the level of plasma free fatty acids as suggested by the results shown in Fig. 1. Although the block of glucose release appeared to be present on both occasions, the assimilation of glucose was clearly less rapid at a time when the patient was able to mobilize free fatty acids in response to hypoglycaemia. Hypoglycaemia was less severe when the capacity of lipolysis improved, even when no change in the block of hepatic glucose release occured. The inverse correlation between the availability of free fatty acids and the percentage of $\mathrm{CO}_{2}$ derived from blood sugar confirms this concept. Fig. 4, which is taken from our first publication on this topic, 
demonstrates the two metabolic blocks which were complete in this particular patient with tumour hypoglycaemia. At the low level of free fatty acids, around $0.4 \mu \mathrm{eq} / \mathrm{ml}$, the percentage of expired $\mathrm{CO}_{2}$ derived from glucose was 60 .

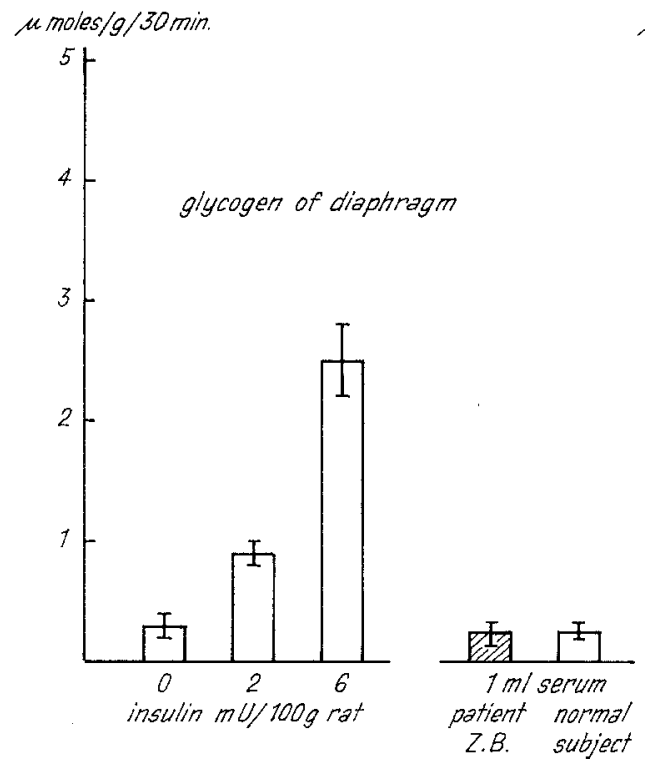

glucose turnover and blocked lipolysis these subjects did not become hypoglycaemic, presumably because the liver was still capable of increasing glucose release. Therefore, a block of hepatic glucose release must accompany the inhibition of lipolysis to cause severe

Fig. 3. Effects of intravenously administered serum of a patient with tumour hypoglycaemia, compared with those of serum of a control subject and of crystalline insulin on the incorporation of glucose-6- ${ }^{14} \mathrm{C}$ into the glycogen of the diaphragm and into the total lipids of the fat pads. Male Osborne-Mendel rats weighing $100 \mathrm{~g}$ were used. They were anaesthetized with diethylaminoallylisopropylbarbituric acid and one hour later the test substances were injected intravenously. After $30 \mathrm{~min}$. the rats were killed by decapitation, the neck blood was collected on ice and the diaphragm and the fat pads were removed for analysis. The counts recovered in the glycogen of the diaphragm and in the total lipids of the fat pads were divided by the specific activity of the blood glucose to express the results as $\mu$ moles of glucose-6- ${ }^{14} \mathrm{C}$ incorporated per $\mathrm{g}$ of tissue and per $30 \mathrm{~min}$. The bars represent the means of the results in 4 rats and the brackets indicate the SEM

A pharmacological block of lipolysis alone does not lead to pronounced hypoglycaemia. CARLson et al. inhibited lipolysis in exercising men by the administration of nicotinic acid [8]. The blood sugar was lower than in control subjects, but despite increased hypoglycaemia. The $K_{G}$ in our patient $Z$. B. varied from normal to elevated values. Although the apparent correlation of low free fatty acids with a rapid glucose turnover might speak in favour of glucose uptake by muscle, this could not be substantiated by arterio-venous glucose differences. According to the results presented in Table 2 the tumour appeared to utilize glucose in an uncontrolled fashion. Thus, the variable glucose consumption by the tumour seems to aggravate hypoglycaemia, the principle cause of which is the invariable inability of the liver to release glucose in sufficient quantities.

Since the mechanisms underlying these two metabolic disturbances are still unknown a few speculations may suggest new lines of investigation in further cases of tumour hypoglycaemia.
Table 3. Insulin-like activities and immunoreactive insulin at different blood sugar levels in patient $Z . B$.

Normal fasting values of nonsuppressible ILA: $168+32$; of suppressible ILA: $13 \pm 8$; and of immunoreactive insulin: $22.2 \pm 3.5 \mu \mathrm{U} / \mathrm{ml}$ serum (mean $\pm \mathrm{SEM}$ )

\begin{tabular}{llll}
\hline blood. sugar & $\begin{array}{l}\text { nonsuppressible } \\
\text { ILA } \\
\mathrm{mU} / \mathrm{ml}\end{array}$ & $\begin{array}{l}\text { suppressible } \\
\text { ILA } \\
\mu \mathrm{U} / \mathrm{ml}\end{array}$ & IRI \\
\hline 26 & $\mathrm{ml}$ & 0 & $\mu \mathrm{U} / \mathrm{ml}$ \\
31 & 170 & 0 & 9.5 \\
50 & 240 & 0 & - \\
83 & 270 & 0 & - \\
110 & 410 & 0 & - \\
115 & 116 & 0 & - \\
145 & 240 & 30 & 11.5 \\
& 125 & & 23
\end{tabular}

There are several possible correlations between serum free fatty acids and hepatic glucose production. EzDINLI and SokaL have shown that glucagon stimulates hepatic glucose release much more efficiently than epinephrine, which is active only in pharma- 
cological doses [10]. The effects of glucagon on hepatic gluconeogenesis may be mimicked by increasing the free fatty acid concentration [37]. Therefore, it is the block of hepatic glucose release, and it also led to a rise of the free fatty acid level. However, a normalization of the free fatty acid level in patient Z.B. did

Table 4. Inhibition of spontaneous lipolysis of adipose tissue of fasted-refed rats by the patient's serum and by a control serum, before and after dialysis

Basal glycerol release was $17.3 \pm 1.7 \mu$ moles per g per hour

\begin{tabular}{|c|c|c|c|c|c|c|c|}
\hline \multirow{3}{*}{$\begin{array}{l}\text { serum } \\
\text { dilution }\end{array}$} & $\mathrm{I}$ & II & III & IV & $\mathbf{v}$ & \multicolumn{2}{|c|}{$P<* *$} \\
\hline & \multicolumn{3}{|l|}{ undialysed } & \multicolumn{2}{|l|}{ dialysed } & \multirow[t]{2}{*}{$\mathrm{I}-\mathrm{IV}$} & \multirow[t]{2}{*}{$\mathrm{II}-\mathrm{V}$} \\
\hline & $1: 10$ & $1: 20$ & $1: 50$ & $1: 10$ & $1: 20$ & & \\
\hline & \multicolumn{5}{|c|}{$\%$ inhibition of basal glycerol release, mean \pm SEM } & & \\
\hline Z.B. 52 , 우 & $44.5 \pm 1.6$ & $34.4 \pm 5.3$ & $16.5 \pm 4.5$ & $27.5 \pm 6.2$ & $7.0 \pm 4.1$ & 0.05 & 0.01 \\
\hline normal subject & $44.3 \pm 2.2$ & $13.3 \pm 3.7$ & $4.2 \pm 2.2$ & $13.5 \pm 7.8$ & $2.5 \pm 0.9$ & 0.01 & 0.05 \\
\hline$P^{*}<$ & 0.49 & 0.01 & 0.025 & 0.15 & 0.20 & & \\
\hline
\end{tabular}

$P^{*}=$ difference between the effects of the two sera.

$P^{* *}=$ difference between the effects of the same serum before and after dialysis.
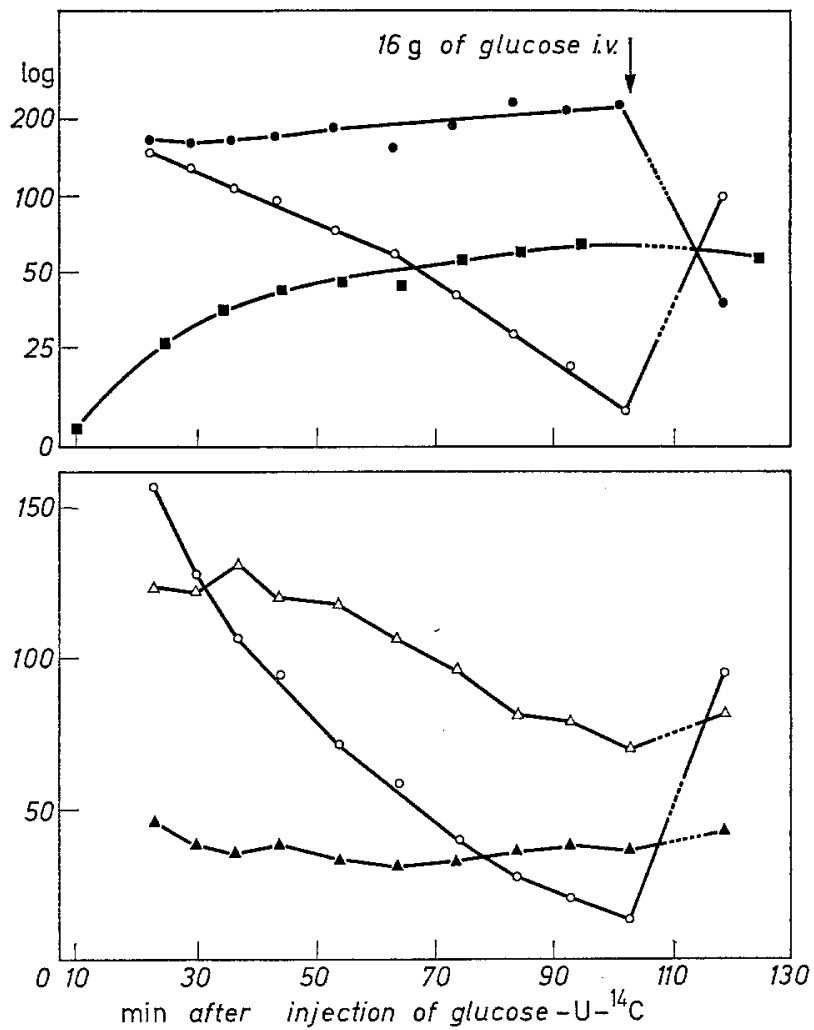

Fig. 4. Metabolism of glucose-U-14 $\mathrm{C}$ during the development of spontaneous hypoglycaemia in patient L.H. 100 $\mu \mathrm{C}$ of glucose- $\mathrm{U}^{14} \mathrm{C}$ was administered together with $44 \mathrm{~g}$ of unlabelled glucose

- - o blood glucose $(\mathrm{mg} / 100 \mathrm{ml})$;

- - specific activity of the blood glucose (cpm/ $/ \mu \mathrm{mole})$;

- - specific activity of expired $\mathrm{CO}_{2}$ (opm/6 $\mu$ moles);

$\triangle-\triangle$ lactic acid $\left(\mathrm{mg} / 100 \mathrm{ml} \cdot 10^{-1}\right)$;

$\Delta$ A plasma free fatty acids $\left(\mu \mathrm{eq} / \mathrm{ml} \cdot 10^{-2}\right)$

conceivable that glucagon acts on hepatic gluconeogenesis by first stimulating lipolysis in the liver, and thereby increasing the free fatty acid level [36, 32]. In both patients, a pharmacological dose of glucagon $1 \mathrm{mg}$ administered intravenously rapidly overcame not prevent hypoglycaemia but retarded its development by lowering the glucose assimilation. Therefore, a direct link between the two blocks of lipolysis and of hepatic glucose release through the level of the free fatty acids is not apparent. It would be of interest to know whether the level of glucagon in these patients is normal, and whether it rises during hypoglycaemia as in normal subjects. Two other hormones which take part in the endocrine counterregulation of hypoglycaemia, growth hormone and epinephrine, rose during hypoglycaemia in patient Z.B.

Thus, the deficiencies of glucose release by the liver and of free fatty acid release by adipose tissue do not appear to be linked together by an endocrine disorder.

A link between the two blocks may be construed by postulating that both reactions, glycogenolysis and lipolysis, might be subject to common inhibitors. Serum of normal subjects inhibited spontaneous lipolysis of adipose tissue of fasted-refed rats more markedly than can be attributed to its content of suppressible and nonsuppressible ILA. After dialysis the antilipolytic effects of serum corresponded to its insulin-like effects on glucose uptake of adipose tissue. The serum of patient Z.B. inhibited lipolysis more markedly than serum of normal subjects, and this additional antilipolytic activity was dialyzable and therefore exerted by a substance of small molecular weight. Several groups of small molecular compounds have been shown to inhibit spontaneous as well as hormonally activated lipolysis of adipose tissue. ATP, ADP, adenosine and other nucleosides and nucleotides are active in concentrations down to $10^{-5} \mathrm{M}$ [21]. These substances are usually present in blood in minute concentrations and it is hardly conceivable that necrotizing tumour tissues might release such compounds in amounts large enough to inhibit lipolysis. Furthermore, these compounds cause flushing, which these patients do not exhibit. Another group of naturally occuring antilipolytic compounds is that of the pro- 
staglandins. We are not aware of any data on the content of prostaglandins in the blood and tumour tissue of these patients.

It has been claimed that lipolysis like hepatic glycogenolysis is activated by cyclic AMP, and that insulin and may be other substances inhibit lipolysis by decreasing the level of cyclic AMP in adipose tissue [5]. However, even the most potent antilipolytic drugs, nicotinic acid and 5-methylpyrazole-3-carboxylic acid which may occasionally lead to a transient depression of the blood sugar through increased glucose uptake by adipose tissue [13], never provoke hypoglycaemia but rather hyperglycaemia when administered over prolonged periods of time [24]. There is no evidence to date that antilipolytic substances may also decrease hepatic glucose release.

We propose a more complex link between the two well documented metabolic disturbances. STLVERSTEIN, WAKIM and BAHN found that mice inoculated with tissue from a lymphatic leukaemic neoplasm exhibited hypoglycaemia. A substance released by the tumour was thought to be responsible for hypoglycaemia [30]. Later, the same authors extended this observation to two patients with tumour hypoglycaemia. Since they observed elevated concentrations of I-tryptophan and its metabolites in the serum of these patients, they postulated that tryptophan might play an important role in the pathogenesis of tumour hypoglycaemia [31].

Many years ago, Mursky demonstrated that 1tryptophan may induce hypoglycaemia in rats [23]. Recently, RAY, Fostrer and LARDY observed that hepatic gluconeogenesis from pyruvate was blocked in rats treated with l-tryptophan [21]. They suggested that the enzyme phosphoenol-pyruvate-carboxy-kinase, which was found to be activated in the liver homogenate of rats pretreated with 1-tryptophan, was "non-functional" in vivo.

Thus, an increased production of tryptophan by the tumour could explain the block of hepatic glucose production. In addition, tryptophan is metabolized to nicotinamide and nicotinic acid among other compounds. Nicotinic acid is a very potent inhibitor of lipolysis. An increased production of tryptophan by the tumour would, therefore, explain both the block of hepatic glucose release as well as the inhibition of lipolysis by its metabolites.

Increased levels of biological ILA in the blood or in the tumour were reported in several cases [3, 34, 7]. The meaning of such findings is questionable if the assay systems were set up for the occasion, since a considerable amount of experience with these techniques is needed. Of the cases discussed in the literature, only one showed a high value of immunoreactive ILA on a single occasion [26]. In our two patients immunoreactive, suppressible and nonsuppressible ILA were normal. If anything, immunoreactive ILA was low, and the B-cells appeared to have lost their ability to respond to glucose with increased insulin secretion.
An "insulinoid" or insulin potentiating substance, suggested by UNGER [33] was searched for by injecting serum of patient Z.B. intravenously into rats together with glucose-6-14C, and by determining the incorporation of carbon ${ }^{14}$ into the diaphragm and the fat pad of the rats. If the serum of patient Z.B. did contain such a substance it should have increased glucose incorporation, which it did not.

Diazoxide did not prevent hypoglycaemia but it clearly delayed its onset. This clear cut amelioration of glucose metabolism was not due to an effect on hepatic glycogenolysis, but rather on lipolysis and glucose consumption. Glycogenolysis was not improved on diazoxide, although this drug has been suggested to affect the rate of glycogenolysis in animals [29].

Endoxan was well tolerated by the patient. However, tumour growth progressed steadily. It is noteworthy that neither of our two patients showed the typical picture of tumour cachexia. Both patients had an ample amount of subcutaneous adipose tissue. This substantiates our chemical finding of blocked lipolysis, which may have led to an accumulation of fat stores.

\section{Literature}

[1] Bergmeyer, H.U., and E. Bernt, in: BergMeyme, H.U.: Methoden der enzymatischen Analyse. Weinheim, Germany, Verlag Chemie, S. 123-130, 1962.

[2] Bertler, A., A. Carcsson and E. Rosengren: A method for the fluorimetric determination of adrenalin and noradrenalin in tissues. Acta physiol. scand. 44, 273-292 (1958).

[3] Bosheid, B.R., J.J. KIRsChenferd and P.S. Soteres: Extrapancreatic insulin-secreting tumor. Now Engl. J. Med. 270, $338-341$ (1964).

[4] Bumra, H., W.A. Mueluer, R.E. Humbel, A. LabHart and E.R. Froesch: Nonsuppressible insulin-like activity of human serum. I. Physicochemical properties, extraction and partial purification. Biochim. biophys. Acta 121, 349-359 (1966).

[5] Butcher, R.W., T.G.T. SNeyd, C.R. PARK and E. W. Sutherland, Jr.: Effect of insulin on adeno$\sin 3$ ', 5'-monophosphate in the rat opididymal fat pad. J. biol. Chem. 241, 1651-1652 (1966).

[6] Butterfield, W.J.H., C.H. Kinder and R.F. MaHLER: Hypoglycemia associated with sarcoma. Lancet 1960 I, 703 .

[7] Carey, R.W., T.G. Premlow, E.Z. Ezdinlr and J.F. Holland: Studies on the mechanism of hypoglycemia in a patient with massive intraperitoneal leiomyosarcoma. Amer. J. Med. 40, 458-469 (1966).

[8] Carlson, L.A., R.J. Haver, L. G. Ekmlund and A. HoLmGREN: Effect of nicotinic acid on the turnover rate and oxidation of the free fatty acids of plasma in man during exercise. Metabolism 12, $837-845$ (1963).

[9] Conard, V.: Mesure de l'assimilation du glucose Editions Acta med. belg. 1955.

[10] EzDinur, E.Z., and J.E. Sokal: Comparison of glucagon and epinephrine effects in the dog. Endocrinology 78, $47-54(1966)$.

[11] Folch, J., M. Lees and G.H. Slonne Stanley: A simple method for the isolation and purification of total lipids from animal tissues. J. biol. Chem. 226, $497-509$ (1957). 
[12] Fromsch, E.R., H. Buergi, P. Bally and A. LabIIART: Insulin inhibition of spontaneous adipose tissue lipolysis and effects upon fructose and glucose metabolism. Mol. Pharm. I, 280-296 (1965).

[13] - W.A. Muelier, R. E. Humbel, A. JAKob and A. LaBHaRT: Nonsuppressible insulin-like activity of human serum: Purification, physicochemical and biological properties and its relation to total serum ILA. Recent Progr. Hormono Res. 23, 565-616 (1967).

[14] - - E.B. RAMLEIER, P. BALLY and A. LABHART: Antibody-suppressible and nonsuppressible insulinlike activities in human serum and their physiological significance. An insulin assay with adipose tissue of increased precision and specificity. J. clin. Invest. 42, 1816-1834 (1963).

[15] - W. Ziegler, P. Bally and A. Labhart: Zur Pathogenese der tumorbedingten Hypoglykämie ohne Hyperinsulinismus. Schweiz. med. Wschr. 93, $1250-1255(1963)$.

[16] - W. A. Muelter, H. Buergi, M. Waldvoget and A. LABHART: Nonsuppressible insulin-like activity of human serum. II. Biological properties of plasma extracts with nonsuppressible insulin-like activity. Biochim. biophys. Acta 121, 360-374 (1966).

[17] GondoN, R.S., JR.: Unesterified fatty acids in human blood plasma. II. The transport function of unesterified fatty acids. J. clin. Invest. 36, 810-815 (1957).

[18] HALES, E.N., and P.J. RANDLE: Immunoassay of insulin with insulin-antibody precipitate. Biochem. J. 88, 137-146 (1963).

[19] Hobes, C.B., and A.L. Mrcren: Review of endocrine syndroms associated with tumors of nonendocrine origin. J. clin. Path. 19, 119-127 (1966).

[20] Jakob, A., N. LaUper, R. Flury, A. LabHart and E.R. Frowsch: Pathogenesis of tumor hypoglycemia. Diabetologia 2, 202-203 (1966).

[21] KAPPELER, H.: Zur Pharmakologie der Lipolysehemmung. I. Wirkungsweise adenosinhaltiger $\mathrm{Nu}$ cleoside und Nucleotide auf die Lipolyse des Fettgewebes in vitro. Diabetologia 2, 52-61 (1966).

[22] Marks, V., and E. SAMols: Hypoglycemia of nonendocrine origin (non-islet cell tumors). Proc. roy. Soc. Med. 59, 338-340 (1966).

[23] Mrrsky, I.A.: Insulinase and Diabetes mellitus. Recent Progr. Hormone Res. 13, 429-471 (1957).

[24] Molnar, G.D., K. G. Borge, J.W. Rosevater, W.F. Mc GUCKIN and R.W.P. AcHor: The effect of nicotinic acid in diabetes mellitus. Metabolism 13, 181190 (1964).

[25] Odeli, W.D., in : Lipsett, M. B., W.D. Odelt, L. E. RosenBERG and T.A. WALDMANN: Hormonal syndromes associated with nonendocrine tumors. Ann. Int. Med. 61, 733-756 (1964).
[26] Oleesky, S., I. Bailey, E. Samols and D. Bilkus: A fibrosarcoma with hypoglycemia and high serum insulin level. Lancet 1962 II, 378-380.

[26a] Papaionnnou, A.N.: Tumors other than insulinomas associated with hypoglycemia. Surg.Gyn. Obstetr. 123, 1093-1109 (1966)

[27] Ray, P.D., D.O. Foster and H.A. Lardy: Paths of carbon in gluconeogenesis. IV. Inhibition by ltryptophan of hepatic gluconeogenesis at the level of phosphoenolpyruvate formation. J. biol. Chem. 241, 3904-3908 (1966).

[28] Samols, E.: Hypoglycemia in neoplasia. Postgrad. med. J. 39, 634-638 (1963).

[29] Schultz, G., G. Sentr, W. Losert and R. Sitt: Biochemische Grundlagen der Diazoxid-Hypergly. kämie. Naunyn-Schmiedeberg's Arch. exp. Path. Pharmak. 253, 372-387 (1966).

[30] Stuverstein, M.N., K.G. Wakim and R.C. Bafin: Hypoglycemia associated with neoplasia. Amer. J. Med. 36, 415-423 (1964).

[31] - - Further observations on the role of tryptohan and its metabolites in hypoglycemia associated with neoplasia. Clin. Res. Proc. 13, 334 (1965).

[32] Struck, E., J. Ashmore and O. Wreland: Stimulierung der Gluconeogenese durch langkettige Fettsäuren and Glucagon. Biochem. Z. 343, 107-110 (1965).

[33] UNGer, R.H.: The riddle of tumor hypoglycemia. Amer. J. Med. 40, 325-330 (1966).

[34] Whitney, J.E., and B.J. HezLeR: Increased insulin-like activity of serum in a patient with spontaneous hypoglycemia associated with retroperitoneal fibrosarcoma. Amer. J. Med. 30, 633-636 (1961).

[35] Wieland, O., in: Bergmeyer H.U.: Methoden der enzymatischen Analyse. Weinheim, Germany, Verlag Chemie, S. 211-214, 1962.

[36] Williamson, J.R.: Mechanism for the stimulation in vivo of hepatic gluconeogenesis by glucagon. Biochem. J. 101, 11c-14c (1966).

[37] - R.A. Kreisberc and P.W. Felts: Mechanism for the stimulation of gluconeogenesis by fatty acids in perfused rat liver. Proc. nat. Acad. Sci. 56, 247$254(1966)$

[38] ZAHND, G.R., and A. LuYCKX: Sécrétion ot action diabétogène de l'hormone de croissance hypophysaire. Helv. med. Acta 32, 332-340 (1965).

Dr. A. JAKOB

Dr. E.R. FromsCH

Kantonsspital Zürich

Medizinische Universitätsklinik

CH-8006 Zürich, Schweiz 